\title{
Molecular characterization of virulence genes and antibiotic resistance among fecal Escherichia coli isolated from surface water of Wadi Shueib-Jordan
}

Shereen Z. Burjaq ${ }^{1}$, Saeid M. Abu-Romman², Moawya A. Haddad ${ }^{3}$

\section{Abstract}

Objective: Contamination of surface water with pathogenic organism is highly dangerous for people who used it for drinking or for domestic activities. Detection of Escherichia coli in water can be used as a general important indicator of fecal contamination. This study investigated the occurrence of fecal $E$. coli, two important toxigenic types of $E$. coli isolates and their antimicrobial resistance in water samples collected from the surface running source of Wadi Shueib in Jordan.

Methods: A total of 51 water samples were collected from three different locations of wadi shueib over a three month, July through September, 2016. For each sample, $200 \mathrm{ml}$ of water was collected in sterilized containers. All samples which were positive for fecal $E$. coli were subcultured on Eosin Methylelne Blue Agar and incubated at $37{ }^{\circ} \mathrm{C}$ for 24 hours. E. coli isolates were identified by API- 20 E test, and all isolates were tested for antimicrobial susceptibility and for the presence of virulence genes of enterotoxigenic E.coli (ETEC) and enterohaemorrhagic E.coli (EHEC).

Results: A total of 46/51 (90\%) of water samples were contaminated with fecal $E$. coli. The $46 \mathrm{E}$. coli isolates were resistant in the range between $4 \%-76 \%$ to commonly used antibiotics in the treatment of infection in Jordan. Multidrug resistant isolates to at least three antibiotics accounted for $17 / 46$ (37\%) of the isolates. Out of 46 fecal $E$. coli isolates, 4 (8.7\%) were ETEC and 2 (4.3\%) were EHEC as detected using PCR.

Conclusion: This study indicated that the surface running water of Wadi Shueib is contaminated with potential enteropathogenic E. coli,
1 Department of Medical Analysis, Faculty of Science, Al-Balqa' Applied University, Salt, Jordan

2 Department of Biotechnology, Faculty of Agricultural Technology, Al-Balqa Applied University Salt, Jordan.

3 Department of Nutrition and Food Processing, Faculty of Agricultural Technology, Al-Balqa Applied University Salt, Jordan.

Contact information:

Shereen Z. Burjaq.

झ shereen.burjaq@bau.edu.jo 
and it can be a source of causing diarrheal diseases. Fecal E. coli isolates from water also showed high level of antibiotic resistance comparable to human $E$. coli isolates in Jordan.

\section{Keywords}

Fecal E. coli; ETEC; EHEC; Antimicrobial Resistance; Surface Water; Jordan.

\section{Introduction}

The quality and availability of fresh safe water is an essential element in health and living for every human community [1-2]. Water borne infection are still a major public health concern in most developing countries [3].

Jordan is considered as one of the ten most water scarce countries in the world. High population growth and flow of hundred thousands of refugees from other Arab countries, have aggravated the shortness of ground water reserves in the country [4]. Therefore, every drop of water should be considered important for usage in human activities and agriculture [5].

Wadi Shueib represents a draining area of approximately 180 square kilometers (69 sq mi). Towns and villages along the wadi include Salt, fuheis and Mahis. These discharge treated and untreated sewage into wadi Shueib course. Therefore, high load of biological contaminants, especially waterborne microbial pathogens, would be expected.

$E$. coli is the most commonly used indicator of fecal contamination in drinking water distribution systems. E. coli of enteric origin can persist with other enteric bacteria and parasites for long time in water, and can be usedt as indicator of water contamination [6]. E. coli survives in drinking water between 4 and 12 weeks, depending on many environmental conditions [7].

Antimicrobial resistance genes are widely distributed in human intestinal bacterial flora, particu- larly in gram negative enteric bacteria contaminated aquatic environment [8]. In water, bacteria of different human and animal origins are able to mix with environmental commensal bacteria and contribute for transfer of antibiotic resistance genes [9]. In recent years, infections caused by multidrug resistant (MDR) pathogenic bacteria have severe health implication in patients and offer limited treatment options [10]. Many diarrheagenic E. coli types can be also associated with contamination of water, particularly ETEC, EHEC and enteropathogenic E. coli (EPEC) [11]. The implementation of PCR methods can easily and rapidly identify diarrheagenic $E$. coli in water and human stool samples [12].

This study aimed to investigate the general occurrence of $E$. coli and particularly the presence of enterotoxigeneic and entereohemorrhagic $E$. coli in water of Wadi Shueib and their antibiotic resistance profiles.

\section{Material and Method}

\section{Water samples collection}

Water samples were collected from three different locations of Wadi Shueib; water springs before AlSalt wastewater treatment plant, treated water immediately after Al-Salt wastewater treatment plant (WWTP) and final region of surface water before Wadi Shuaib Dam. For each sample, $200 \mathrm{ml}$ of water was collected in sterilized containers (glass bottles). 
When the sample was collected, an ample air space was left in the bottle $(2.5 \mathrm{~cm})$ to facilitate mixing and shaking before examination. Bottles were fully submerged in the water, then immediately covered by the sterilized lid according to the guidelines of the American Public Health Association [13]. The samples were carried in ice box and brought to the laboratory within few hours for microbial analysis.

\section{Isolation of fecal E.coli}

Out each water sample, $1 \mathrm{ml}$ of water was taken and delivered to Lauryl Tryptose broth (Neogen, USA) with inverted durhams tubes, then incubated at $35^{\circ} \mathrm{C}$ for 24 hours, and examined for gas formation or acidic growth. When no gas or acidic growth had formed, inoculated tubes were re-incubated for another 24 hours. To detect fecal E. coli, positive Lauryl Tryptose broth tubes were shaken to resuspend the organism, and with a sterile loop, one loopful of culture was transferred to EC Broth (HiMedia, India) and incubated at $44.5^{\circ} \mathrm{C}$ for 24 hours and examined for growth and gas formation [13]. Test tubes which show positive results were subcultured on Eosin Methylelne Blue (EMB) Agar (HiMedia, India), and were identified by API- 20 E test. E. coli isolates were stored in Brain- Heart Infusion broth (Oxoid, England) with 15\% glycerol in freezer for further examination.

\section{Antibiotic susceptibility test}

E. coli isolates were tested by disk diffusion method against the following antimicrobials (Oxoid, England): Ampicillin $(10 \mu \mathrm{g})$, nalidixic acid $(30 \mu \mathrm{g})$, streptomycin $(10 \mu \mathrm{g})$, ciprofloxacin $(5 \mu \mathrm{g})$, chloramphenicol $(30 \mu \mathrm{g})$, cefotaxime $(30 \mu \mathrm{g})$, cefuroxime (30 $\mu \mathrm{g})$, gentamicin $(10 \mu \mathrm{g})$, tetracycline $(30 \mu \mathrm{g})$ cotrimoxazol $(25 \mu \mathrm{g})$ amikacin $(30 \mu \mathrm{g})$, piperacillintazobactam $(100 / 10 \mu \mathrm{g})$, impeneme $(10 \mu \mathrm{g})$, meropenem $(10 \mu \mathrm{g})$, azetreonam $(30 \mu \mathrm{g})$, and ceftazidime $(30 \mu \mathrm{g})[2,14]$. Antimicrobial susceptibility testing was performed according to the recommendation of the Clinical Laboratory and Standards Institute/ CLSI [15]. The results were interpreted according to the guidelines of CLSI. E. coli ATCC 25922 strain was included as a control was obtained from Dr. Asem Shehabi, The Jordan University, Amman, Jordan.

\section{Detection and characterization using PCR}

All DNA of $\mathrm{E}$. coli isolates and control $\mathrm{E}$. coli strains were extracted using Wizard ${ }^{\circledR}$ Genomic DNA Purification Kit (promega, USA). Control strains of EHEC (ATCC 43894) and ETEC (ATCC 35401) (Dr. Asem Shehabi) were included as positive controls. DNA templates of fecal E. coli strains were subjected to multiplex PCR using specific primer (Integrated DNA Technologies, USA) sequences for the detection of virulence genes in ETEC and EHEC as shown in Table 1 [16].

Table 1. Primers used in the multiplex PCR for the detection of ETEC and EHEC [16].

\begin{tabular}{|c|c|c|c|}
\hline Primer & $\begin{array}{l}\text { Target } \\
\text { gene }\end{array}$ & Primer sequence & $\begin{array}{l}\text { Amplicon } \\
\text { size (bp) }\end{array}$ \\
\hline LT & eltB & $\begin{array}{l}\text { 5'-TCTCTATGTGCATACGGAGC-3' } \\
\text { 5'-CCATACTGATTGCCGCAAT-3' }\end{array}$ & 322 \\
\hline ST & estA & $\begin{array}{l}\text { 5'-GCTAAACCAGTAGGGTCTTCAAAA-3' } \\
\text { 5'-CCCGGTACAGGCAGGATTACAACA-3' }\end{array}$ & 147 \\
\hline VT1 & vt1 & $\begin{array}{l}\text { 5'-GAAGAGTCCGTGGGATTACG-3' } \\
\text { 5'-AGCGATGCAGCTATTAATAA-3' }\end{array}$ & 130 \\
\hline VT2 & vt2 & $\begin{array}{l}\text { 5'-ACCGTTTTTCAGATTTTGCACATA-3' } \\
\text { 5'-TACACAGGAGCAGTTTCAGACAGT-3' }\end{array}$ & 298 \\
\hline eae & eaeA & $\begin{array}{l}\text { 5'-CACACGAATAAACTGACTAAAATG-3' } \\
\text { 5'-AAAAACGCTGACCCGCACCTAAAT-3' }\end{array}$ & 376 \\
\hline
\end{tabular}

In addition to the primers, the mixture contain $12.5 \mu \mathrm{l}$ master mix (Promega, USA), $2 \mu$ purified DNA and a $0.2 \mu \mathrm{M}$ concentration of each primer except primer VT1 (which was used at a concentration of $0.4 \mu \mathrm{M})$. PCR reactions were performed in a total reaction volume of $20 \mu \mathrm{l}$. The amplification conditions were as the following: $96^{\circ} \mathrm{C}$ for $4 \mathrm{~min}$, $94^{\circ} \mathrm{C}$ for $20 \mathrm{~s}, 55^{\circ} \mathrm{C}$ for $20 \mathrm{~s}$, and $72^{\circ} \mathrm{C}$ for $30 \mathrm{~s}$ for 30 cycles, with a final $7-$ min extension at $72^{\circ} \mathrm{C} .10$ $\mu \mathrm{l}$ of each PCR product was evaluated with a $1.5 \%$ (wt/vol) agarose gel (Bio Basic Inc., USA) stained with ethidium bromide. Agarose gel electrophoresis was run for $30 \mathrm{~min}$ at $120 \mathrm{~V}$ [16]. A $50 \mathrm{bp}$ ladder (iNtRON Biotechnology, USA) was used as control. 
After electrophoresis was completed the gel was visualized under ultraviolet light.

\section{Results}

\section{Incidence of fecal $E_{\text {. coli }}$ in water}

In order to evaluate the presence of fecal $E$. coli in water, a total of 51 water samples were collected from Wadi Shueib. The water samples were examined using a protocol for the presence of fecal $E$. coli and the results showed that 46 samples (90.2\%) showed contamination with fecal E. coli (Table 2).

Table 2. Distribution of fecal $E$. coli in water samples collected from Wadi Shueib.

\begin{tabular}{|l|c|c|c|}
\multicolumn{1}{|c|}{$\begin{array}{c}\text { Collection site of water } \\
\text { sample }\end{array}$} & $\begin{array}{c}\text { no. of } \\
\text { samples }\end{array}$ & $\begin{array}{c}\text { No. of fecal } \\
\text { E. coli isolates }\end{array}$ & $\%$ \\
\hline Water springs & 17 & 15 & 88 \\
\hline Immediately after Al-Salt wwtp & 17 & 16 & 94 \\
\hline Before Wadi Shuaib Dam & 17 & 15 & 88 \\
\hline
\end{tabular}

\section{Antimicrobial resistance of 46 fecal E. coli isolates}

Antimicrobial resistance rates of $E$. coli isolates are shown in Table 3. Out of 46 E. coli strains, 17 (37\%) isolates were resistant to at least three antibiotic classes and considered multidrug resistant (MDR) isolates[17]. Most of these MDR isolates were isolated from water springs (Table 3, 4).

\section{Incidence of ETEC and EHEC isolates}

Out of 46 fecal E. coli isolates, 4 (8.7\%) were ETEC and 2 (4.3\%) were EHEC as detected using PCR (Table 5).

\section{Discussion}

This study demonstrates that the surface water of Wadi Shuaib is highly contaminates with fecal $E$. coli, since $46 / 51$ (90.2\%) of the water samples were found contaminated with fecal $E$. coli. The isolates were resistant in the range $4 \%-76 \%$ to commonly
Table 3. Resistance rates of 46 fecal $E$. coli isolates to antimicrobial agents.

\begin{tabular}{|l|c|c|}
\hline \multicolumn{1}{|c|}{ Antimicrobial agent } & No. of resistant isolates & $\%$ \\
\hline Ampicillin (AM) & 35 & 76.1 \\
\hline Tetracycline (TE) & 19 & 41.3 \\
\hline Streptomycin (S) & 10 & 21.7 \\
\hline Cotrimoxazol (STX) & 12 & 26.1 \\
\hline Nalidixic acid (NA) & 8 & 17.4 \\
\hline Azetreonam (ATM) & 4 & 8.7 \\
\hline Ceftazidime (CAZ) & 4 & 8.7 \\
\hline Ciprofloxacin (CIP) & 4 & 8.7 \\
\hline Cefotaxime (CTX) & 2 & 4.3 \\
\hline Gentamicin (CN) & 2 & 4.3 \\
\hline Amikacin (AK) & 0 & 0.0 \\
\hline Impeneme (IMI), & 0 & 0.0 \\
\hline Meropenem (MEM) & 0 & 0.0 \\
\hline Tazobactam (PTZ) & 0 & 0.0 \\
\hline
\end{tabular}

Table 4. Distribution of MDR E. coli isolates in water samples collected from different location along the water flow.

\begin{tabular}{|l|c|c|c|}
\multicolumn{1}{|c|}{$\begin{array}{c}\text { Collection site of water } \\
\text { sample }\end{array}$} & $\begin{array}{c}\text { no. of } \\
\text { samples }\end{array}$ & $\begin{array}{c}\text { No. of MDR } \\
\text { E. coli isolates }\end{array}$ & $\%$ \\
\hline Water springs & 15 & 8 & 53.3 \\
\hline Immediately after Al-Salt wwtp & 16 & 3 & 18.8 \\
\hline Before Wadi Shuaib Dam & 15 & 6 & 40.4 \\
\hline
\end{tabular}

Table 5. Distribution of virulence genes in 4 ETEC and 2 EHEC isolates from different location of the surface water of Wadi Shuaib.

\begin{tabular}{|c|c|c|c|c|c|c|c|c|c|}
\hline \multirow[b]{2}{*}{$\begin{array}{l}\text { Collection } \\
\text { sites }\end{array}$} & \multirow{2}{*}{$\begin{array}{c}\text { no. of } \\
\text { E. coli } \\
\text { isolates }\end{array}$} & \multirow[b]{2}{*}{ ST } & \multicolumn{2}{|c|}{ LT } & \multicolumn{2}{|c|}{ vt1 } & \multirow{2}{*}{$\begin{array}{l}\text { vt2 } \\
\text { No.* }\end{array}$} & \multicolumn{2}{|c|}{ eaeA } \\
\hline & & & No.* & $\%$ & No.* & $\%$ & & No.* & $\%$ \\
\hline Water springs & 15 & 0 & 1 & 6.7 & 0 & 0.0 & 0 & 0 & 0.0 \\
\hline $\begin{array}{l}\text { After Al-Salt } \\
\text { wwtp }\end{array}$ & 16 & 0 & \multicolumn{2}{|c|}{0} & 1 & 6.3 & 0 & 1 & 6.3 \\
\hline $\begin{array}{l}\text { Before Wadi } \\
\text { Shuaib Dam }\end{array}$ & 15 & 0 & 3 & 20.0 & 1 & 6.7 & 0 & 1 & 6.7 \\
\hline Total & 46 & 0 & 4 & 8.7 & 2 & 4.3 & 0 & 2 & 4.3 \\
\hline
\end{tabular}


used antibiotics in the treatment of infection in Jordan $[8,18]$. A total of 17 (37\%) E. coli isolates were multidrug resistant to three or more antimicrobial classes.

A previous study from Saudi Arabia [2] found that E. coli isolates from Al-Ahsa water springs exhibited high resistance rates as found in our study for the foIlowing antimicrobial agents: tetracycline (50\%), cotrimoxazol (38.5\%), streptomycin (65.4\%), nalidixic acid (42.3\%), and ciprofloxacin (34.6\%). In addition, the percentage rate of multiresistant strains were higher $(57.7 \%)$ than this study (37\%). The important aspect of contamination of running surface water with opportunistic pathogenic bacteria constitutes the occurrence of antibiotic-resistant bacteria of human and animal sources into aquatic environment. Antibiotic resistance genes are introduced in natural bacterial ecosystems through mainly contamination of water with fecal bacteria. In such systems, communsel bacteria in water could acquire antibiotic resistance genes through natural genetic processes such as conjugation and transduction [19]. This study shows that $E$. coli isolates from water samples carried antibiotic resistance profiles comparable to E. coli isolates from human sources in Jordan [18, 19].

Diarrhea caused by pathogenic types of $E$. coli is still a health care problem in developing countries including Jordan, mostly found in children younger than five years old [11, 20, 21]. Among diarrheagenic bacteria, enterotoxigenic and enterohemorrhagic E. coli are important enteropathogens causing single and outbreaks of diarrhea following consumption of contamination of fresh food and drinks [22]. ETEC affects small intestine, and it is still a major cause of traveler diarrhea. It is responsible for 280 million diarrheal episodes and more than 400 thousand death annually [23]. ETEC strains produce one or two types of enterotoxins; heat-stable enterotoxin and heat-labile enterotoxin, encoded by the est $A$ and elt $B$ genes, respectively [24]. While EHEC are more associated with sever outbreak of intestinal infections, and its enterotoxins affect large intestine and leads to severe abdominal pain, watery diarrhea followed by bloody diarrhea and may cause fetal hemolytic uremic syndrome in certain patients. EHEC strains produce verocytotoxins VT1 and/or VT2, which are encoded by the $v t 1$ and $v t 2$ genes, respectively [24]. This study demonstrates that ETEC (8.7\%) is frequently more detected in the surface water than EHEC (4.3\%). The higher incidence of ETEC isolates has also been reported previously in a study performed in Jordan and which has showed that children with diarrhea and without diarrhea carried in their feces mostly EPEC and ETEC [21]. On the other hand, another study in Jordan carried in 2012 showed that non of $E$. coli isolates which contaminated green leafy vegetables, belonged to diarrheagenic E. coli [14]. The higher occurrence of the ETEC type than EHEC strains suggests that human fecal material is the main source of contamination of water sources with fecal E. coli, since EHEC found mostly in feces of animals [25]. Additionally, heat-stable toxin gene (ST gene) is generally found in ETEC of animal origin, while the heat-labile toxin gene (LT gene) is more detected in human isolates (8.7\%) as the case in our study [21].

\section{Conclusion}

This study shows that the surface running water of Wadi Shueib is contaminated with potential enteropathogenic strains of $E$. coli, and this organism can be associated with other potential pathogenic organisms and a source of causing diarrheal and enteric diseases. In addition, fecal E. coli isolates from this Jordanian surface water has showed high percentage of antibiotic resistance. 


\section{Acknowledgements}

The authors thank Dr. Asem Shehabi/The Jordan University, for providing E.coli control strains.

\section{References}

1. Adekunle LV, Sridhar M, Ajayi AA, Oluwade PA, Olawuyi JF. An Assesment of the Health and Social Economic Implications of Satchet Water in Ibadan Nigeria: A Public Health Challenge. Afr J Biomed Res. 2004; 7: 5-8.

2. Alzahrani A, Gherbawy Y. Antibiotic resistance in Escherichia coli strains isolated from water springs in Al-Ahsa Region. Afr. J. Microbiol. Res. 2011 Jan; 5 (2):123-130.

3. Oyedeji O, Olutiola P, Moninuola M. Microbiological quality of packaged drinking water brands marketed in Ibadan metropolis and Ile-Ife city in South Western Nigeria. Afr. J. Microbiol. Res. 2010; 4 (1): 96-102.

4. Lahn G, Grafham O, Sparr A. Refugees and Energy Resilience in Jordan. Retrieved from Reliefweb, UN Office for the Coordination of Humanitarian Affairs (OCHA) 2016. https:// www.chathamhouse.org/.

5. Abu-Sharar T, Battikhi A. Water Resources Management under Competitive Sectoral Demand A Case Study from Jordan. Water International 2002; 27:364-378.

6. Abberton CL, Bereschenko L, van der Wielen PW, Smith CJ. Survival, Biofilm Formation, and Growth Potential of Environmental and Enteric Escherichia coli Strains in Drinking Water Microcosms. Appl Environ Microbiol. 2016 Aug; 82 (17):5320-31.

7. Edberg SC, Rice EW, Karlin RJ, Allen MJ. Escherichia coli: the best biological drinking water indicator for public health protection. Symp Ser Soc Appl Microbiol. 2000; (29):106S-116S.

8. Shehabi AA, Masoud H, Maslamani FA. Common antimicrobial resistance patterns, biotypes and serotypes found among Pseudomonas aeruginosa isolates from patient's stools and drinking water sources in Jordan. J Chemother. 2005 Apr; 17 (2):179-83.

9. Baquero F, Martínez JL, Cantón R. Antibiotics and antibiotic resistance in water environments. Curr Opin Biotechnol. 2008 Jun; 19 (3):260-5

10. Barza M, Travers K. Excess infections due to antimicrobial resistance: the "Attributable Fraction". Clin. Infect. Dis. 2002 Jun 1; 34 Suppl 3:\$126-30

11. Ramadan H, Awad A, Ateya A. Detection of phenotypes, virulence genes and phylotypes of avian pathogenic and human diarrheagenic Escherichia coli in Egypt. J Infect Dev Ctries. 2016 Jun 30; 10 (6):584-91.
12. Salmani H, Azarnezhad A, Fayazi MR, Hosseini A. Pathotypic and Phylogenetic Study of Diarrheagenic Escherichia coli and Uropathogenic E. coli Using Multiplex Polymerase Chain Reaction. Jundishapur J Microbiol. 2016 Feb 2; 9 (2):e28331.

13. American Public Health Association, Water Environment Federation, and American Water Works Association (AWWA).2015. Standard Methods for the Examination of Water and Wastewater, 22nd Edition, Washington DC.

14. Burjaq SZ, Shehabi AA. Fresh leafy green vegetables associated with multidrug resistant E. coli. The International Arabic Journal of Antimicrobial Agents 2013; 3:3.

15. CLSI. Clinical Laboratory and Standards Institute Disk Diffusion: Quality Control Ranges for Nonfastidious Organisms (Unsupplemented Mueller-Hinton Medium), and Zone Diameter and MIC Interpretive Standards for Enterobacteriaceae. CLSI, Villanova, PA, USA.

16. Nguyen TV, Le Van P, Le Huy C, Gia KN, Weintraub A.. Detection and Characterization of Diarrheagenic Escherichia coli from Young Children in Hanoi, Vietnam. J Clin Microbiol. 2005 Feb; $43(2): 755-60$.

17. Magiorakos AP, Srinivasan A, Carey RB, Carmeli Y, Falagas ME, Giske CG, Harbarth S, Hindler JF, Kahlmeter G, Olsson-Liljequist B, Paterson DL, Rice LB, Stelling J, Struelens MJ, Vatopoulos A, Weber JT, Monnet DL. Multidrug-resistant, extensively drugresistant and pandrug-resistant bacteria:an international expert proposal for interim standard definitions for acquired resistance. Clin Microbiol Infect. 2012 Mar; 18 (3):268-81

18. Al-Mardeni RI, Batarseh A, Omaish L, Shraideh M, Batarseh B, Unis N. Empirical treatment for pediatric urinary tract infection and resistance patterns of uropathogens, in Queen Alia hospital and prince A'Isha military center Jordan. Saudi J Kidney Dis Transpl. 2009 Jan; 20 (1):135-9.

19. Shehabi AA, Odeh JF, Fayyad M. Characterization of antimicrobial resistance and class 1 integrons found in Escherichia coli isolates from Jordanian Human Stools and Drinking Water Sources. J Chemother. 2006; 18, 5: 468-47.

20. Heidary M, Momtaz H, Madani M. Characterization of Diarrheagenic Antimicrobial Resistant Escherichia coli Isolated From Pediatric Patients in Tehran, Iran. Iran Red Crescent Med J. 2014 Apr; 16 (4):e12329.

21. Shehabi AA, Bulos NK, Hajjaj KG. Characterization of diarrhoeagenic Escherichiah coli isolates in Jordanian children. Scand J Infect Dis. 2003; 35 (6-7):368-71. 
22. Kazemi R, Akhavian A, Amani J, Salimian J, Motamedi MJ, Mousavi A, Jafari M, Salmanian AH. Immunogenic properties of trivalent recombinant protein cmposed of B-subunits of LT, STX-2, and CT toxins. Microbes Infect. 2016 Jun; 18 (6):421-9.

23. Steffen R, Castelli F, Dieter Nothdurft $H$, Rombo $L$, Jane Zuckerman N.Vaccination against enterotoxigenic Escherichia coli, a cause of travelers' diarrhea. J Travel Med. 2005 Mar-Apr; 12 (2):102-7.

24. Persson S, Olsen KE, Scheutz F, Krogfelt KA, Gerner-Smidt P. A method for fast and simple detection of major diarrhoeagenic Escherichia coli in the routine diagnostic laboratory. Clin Microbiol Infect. 2007 May; 13 (5):516-24.

25. Sidhu JP, Ahmed W, Hodgers L, Toze S. Occurrence of Virulence Genes Associated with Diarrheagenic Pathotypes in Escherichia coli Isolates from Surface Water. Appl Environ Microbiol. 2013 Jan; 79 (1):328-35.

Publish in The International Arabic Journal of Antimicrobial Agents

The Journal is an open access peer-reviewed journal that publishes scientific papers about all aspects of antimicrobials. The journal will publish original research articles, reviews, brief reports and case reports dealing with basic and clinical antibacterial agents, antiviral, antiprotozoals, antituberculuous, antifungal and antihelminthes agents. All manuscripts must be prepared in English, and are subject to a rigorous and fair peer-review process. Accepted papers will immediately appear online. The journal aims to advance the knowledge, attitude and the research of chemotherapy in the Arabic world in cooperation with international, national scientific and public societies as well as research centers with similar aims and objectives. 